\title{
Heavy Metal Concentrations in the Tissues of Synodontis Membranaceous along Lower Taylor Creek, Bayelsa State Nigeria.
}

\author{
Ogaga Augustine Aghoghovwia, Tari Timothy Edike \\ Department of Fisheries/Livestock Production Techonology Niger Delta University, Wilberforce Island Bayelsa \\ State-Nigeria.
}

\begin{abstract}
Heavy metal concentrations were determined in fish tissues of Synodontis membranaceous from Taylor creek in Bayelsa state using Atomic Absorption Spectrophotometer (AAS). The result indicated that the level of Zn $(0.991 \mu \mathrm{g} / \mathrm{g})$ in the tissues had the highest concentration value of all the detected heavy metals and the least was $\mathrm{Cd}(0.01 \mu \mathrm{g} / \mathrm{g})$. The trend of heavy metals concentration are in the order $\mathrm{Zn}>\mathrm{Mn}>\mathrm{Pb}>\mathrm{Cd}$ in the fish (Synodonlis membraneceous) tissues with a significant difference at $P<0.05$. The metals varied significantly $(P<0.05)$ across the stations and metal values were generally in the order station $2>$ station $3>$ station 1. Heavy metal levels in the tissues ( $\mathrm{Mn} 0.274 \mu \mathrm{g} / \mathrm{g}, \mathrm{Pb} 0.46 \mu \mathrm{g} / \mathrm{g}$ and $\mathrm{Cd} 0.020 \mu \mathrm{g} / \mathrm{g}$ ) were all greater than the maximum acceptable limits in food fish meant for human except for Zn. This thus indicated contamination to levels that could pose potential hazard when consumed. It is therefore inferred that the fisheries of the creek are unfit for human consumption. Based on the above findings, close monitoring involving human health risk assessment in relation to environment pollution of Taylor Creek is strongly recommended.
\end{abstract}

Keywords: Heavy metals, Aquatic organisms, Taylor creek, Environmental pollution, Fish tissues.

\section{Introduction:}

Water is one of the most valuable natural resources. The quality of water is of vital concern for mankind since it is directly linked with human welfare (Kumar, 2004). Controlled and uncontrolled disposal of waste, accidental and process spillage, mining and smelting of metalliferous ores, sewage sludge application to agricultural soils are responsible for transference of contaminants into non-contaminated sites as dust or leachate and contribute towards contamination of our ecosystem (Glosh and Singh, 2005).

Skjelvale et al., (2001) reported that it is difficult to find a river or other water bodies which the natural regime has not been modified by man's activities. Urbanization and industrialization are associated with more products, produced from a variety of sources and are indiscriminately deposited without proper treatment (Parson, 1995). This indiscriminate and unsanitary deposition of wastes brings about pollution of water by substances which affect the lives in it (Gbaruko and Friday, 2007).

Heavy metals refer to any metallic element that has a relatively high density and is toxic even at low concentration (Lenntech, 2004). Okoye et al., (1991) stated that natural source may include volcanic activity, continental weathering and forest fires, while anthropogenic sources may include industrial effluents, urban storm, water runoff, leaching of metals from garbage and solid dump, metal input from garbage and solid dump, metal input from rural areas. Minor sources may include fumes from automobile exhaust (Brock, 1985).

There is increasing concern about the effects and fate of heavy metals in the

Nigerian environment (Omoniyi et al., 2006). Heavy metals are easily absorbed by aquatic life forms and accumulation may occur in higher concentration than parent water bodies (Deb and Sandra, 1997). Omoregie et al., (2002). The use of fish and invertebrates as bioicators of water quality has been advocated by several workers (Aghoghovwia, 2008. Omoniyi et al., 2006.Omoregie et al., 2002. Deb and Santra, 1997., and Yamazaki et al.,1996) .

Agbozu and Ekweozor (2004) as well as Agbozu et al., 2000 in their respective studies of heavy metals in fish along various axes of Taylor Creek, revealed that the levels of heavy metals were high. It is also glaring that information concerning the fate of the Taylor Creek till date is scanty. There is the need to know current status of the creek, thus this study was carried out to investigate the recent trend of heavy metals along the creek with emphasis on Synodontis membraneceous which is of commercial significance to the area. 


\section{Materials And Methods}

\section{Study Area}

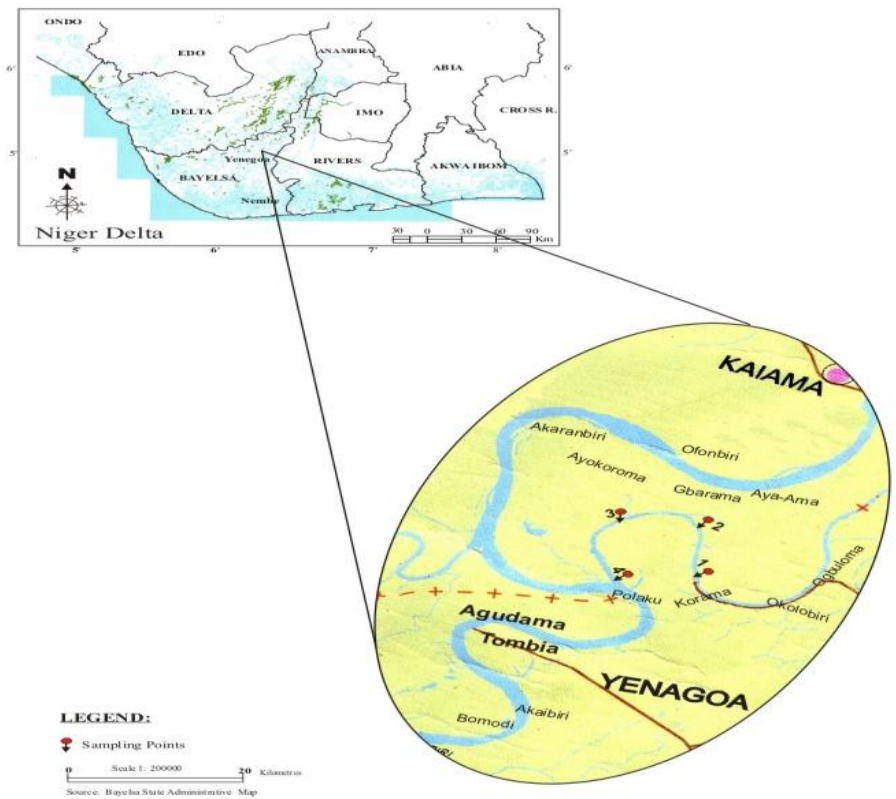

The study was carried out in Taylor creek, a non-tidal fresh water body in Gbaran clan of Yenagoa local government area of Bayelsa State, Southern Nigeria (Fig. 1). The creek lies between longitude $6^{0} 17^{1}$ to $6^{0} 21^{1} \mathrm{E}$ and latitude $5^{0} 1^{1}$ to $5^{0} 5^{1} \mathrm{~N}$ respectively and enjoys a humid tropical climate characterized by the hot wet conditions which are dry and wet seasons. The entire stretch of the creek from Agbia/Nedugo to Polaku is about $16 \mathrm{~km}$ (Agbozu and Kweozor, 2001).

\section{Sampling Stations}

The study area was divided into three sampling stations. Station is located at Agbia and had low population and industries, while station 2 - Ogboloma has oil pipelines, high population density and many toilets built directly on the stretch of the creek. Station 3-Polaku hosts the Liquefied Natural gas LNG Company and it is the point at which the creek empties into the River Nun.

\section{Fish Sample Collection}

Fish samples were obtained from catches with nets thrown overnight by fishermen at selected 3 stations respectively on prior arrangement. The samples were fairly of the same size and random samples of three catch from the station were collected and immediately labeled and transferred to a plastic container containing ice and taken to the laboratory. The samples were kept in a freezer/ prior analysis.

\section{Sample Preparation/Heavy Metal Analysis:}

Samples were taken from the freezer and allowed to defrost at room temperature. The samples were then oven dried and Pulverized to fire texture and stored in air tight labeled plastic container for analysis.

Two grams of the Pulverized samples were weighed using a high precision electronic scale model Ohaus LS 2000 and put into a digestion sample and subsequently $5 \mathrm{ml}$ of $10 \%$ concentrated nitric acid was added to the digestion. The contents of the flask was for each case digested gently and slowly in a water bath until the content got to near dryness and was set aside to cool after brown fumes which later turned white and evaporated.

The content in the digestion flask was the filtered into a standard volumetric flask and diluted with distilled water. The solution was then passed to the atomic absorption spectrometer (AAS) for determination of the concentration of the various metals.

VI. Statistical Analysis:

The data obtained in the study were analyzed (ANOVA) to test for significant difference between metals detected in fish and across the stations at $5 \%$ level of significance. 


\section{Result And Discussion:}

The study as revealed in the Table 1 , showed the metals to be in the ranges $\mathrm{Pb}(0.012-0.46) \mu \mathrm{g} / \mathrm{g}$, $\mathrm{Cd}(0.001-0.020) \mu \mathrm{g} / \mathrm{g}, \mathrm{Mn}(0.075-0.274) \mu \mathrm{g} / \mathrm{g}$ and $\mathrm{Zn}(0.517-0.991 \mu \mathrm{g} / \mathrm{g}$. the highest values for reach of the metals were recorded in station 2, While station 1 had the least values. In each of the stations, $\mathrm{Zn}$ recorded the highest values $(0.517,0.991$ and 0.517$)(\mu \mathrm{g} / \mathrm{g}$ for stations 1,2 and 3 respectively whereas $\mathrm{Cd}$ had the least values $(0.001,0.20$ and 0.004$) \mu \mathrm{g} / \mathrm{g}$ for stations 1,2 and 3 . There was a significant level of difference between the metals and across the stations at $\mathrm{P}<09.05$.

Table 1: Mean concentration of heavy metals $(\mu \mathrm{g} / \mathrm{g})$ in the tissues of Synodontis membranaceous.

\begin{tabular}{llll}
\hline \multicolumn{1}{c}{ HEAVY METALS } & SAMPLING STATIONS & & \\
\hline & STATION 1 & STATION 2 & $0.041 \pm 0.001$ \\
$\mathrm{~Pb}$ & $0.012 \pm 0.001$ & $0.046 \pm 0.002$ & $0.004 \pm 0.001$ \\
Mean SD & $0.001 \pm 0.001$ & $0.020 \pm 0.001$ & $0.084 \pm 0.002$ \\
CD & $0.075 \pm 0.001$ & $0.274 \pm 0.001$ & $0.517 \pm 0.001$ \\
Mean SD & $0.0517 \pm 0.002$ & $0.991 \pm 0.002$ & \\
Mn & & & \\
Mn Sn & &
\end{tabular}

$\mathrm{SD}=$ Standard Deviation

Table 2: Recommended acceptable limit of heavy metals $(\mu \mathrm{g} / \mathrm{g})$ in fish food.

\begin{tabular}{ccc}
\hline METALS & WHO & CIFA \\
\hline $\mathrm{Mn}$ & 0.01 & 0.01 \\
$\mathrm{Zn}$ & 5.00 & 20.00 \\
$\mathrm{Cd}$ & 0.01 & 0.02 \\
$\mathrm{~Pb}$ & 0.05 & 0.03 \\
$\mathrm{Ni}$ & 0.05 & 0.05 \\
$\mathrm{Cu}$ & 1.00 & $<1.00$ \\
\hline
\end{tabular}

Adapted from: WHO,1985; CIFA, 1994

\section{Discussion:}

The result of this investigation revealed that the mean level of the metal $\mathrm{Zn}(0.517,0.991$ and 0.517$)$ $\mu \mathrm{g} / \mathrm{g}$ in the tissues of the fish was high across the stations. Stations 2 had higher mean level of heavy metal concentration when compared to stations 1 and 3 . The possible explanation for this could be the closeness of the station 2 to the source of the Etelebou Creek, a tributary which empties the effluents the oil industry (Flow station) into the Taylor Creek.

The study showed that accumulated metals varied within the stations as well as between the stations. The metal values were in the order $\mathrm{Zn}>\mathrm{Mn}>\mathrm{Pb}>\mathrm{Cd}$ across the stations. The heavy metal concentrations in this study were much lower than those reported by Agbozu et al., (2002) for the Niger Delta areas. This might be due to the fact that oil industrial activities in the area had reduced significantly at the time of the study. The level of $\mathrm{Zn}(0.51-0.991) \mu \mathrm{g} / \mathrm{g}$ recorded in the tissue of this study is higher than those documented by Obafemi (2010) in River Alakata-Ogun State, Nigeria, but much lower than values computed by Obasohan, et al., (2006) in Ikpoba river $(16.778 \mathrm{gh} / \mathrm{g})$ and Ogbia river $(13.67 \mu \mathrm{g} / \mathrm{g})$ in Benin City Edo State respectively.

$\mathrm{Mn}$ and $\mathrm{Zn}$ are essential elements for the growth and wellbeing of living organisms. However the values generated in this work for Mn $0.075 \pm 0.001 \mu \mathrm{g} / \mathrm{g} \quad 0.274 \pm 0.001 \mu \mathrm{g} / \mathrm{g}$ and $0.084 \pm 0.002 \mu \mathrm{g} / \mathrm{g}$ ) were generally higher when compared to the recommended acceptable limit in fish food $0.01 \mu \mathrm{g} / \mathrm{g}$ 5et by WHO (1985) and CIFA (1994). These high values detected in fish tissues could according to Hayat et al., (2007) impair physiological functions, individual growth, reproduction and influence mortality. On the other hand, Cd and $\mathrm{Pb}$ are not essential for metabolic activities hence exhibit toxic properties. Although findings in this research revealed that $\mathrm{Pb}(0.012 \pm 0.0011 \mu \mathrm{g} / \mathrm{g}, 0.046 \pm 0.002 \mu \mathrm{g} / \mathrm{g}$ and $0.041 \pm 0.001 \mu \mathrm{g} / \mathrm{g})$ obtained in fish tissues are lower than the values $(0.05 \mu \mathrm{g} / \mathrm{g})$ specified by WHO (1985) Table 2 . The risk appears, to be imminent essentially at stations 2 and $3(0.046$ and $0.041 \mu \mathrm{g} / \mathrm{g})$ which are higher than the acceptable limit in food as recommended by CIFA (1994). The clinical signs of $\mathrm{Pb}$ include inhibition of synthesis of hemoglobin, dysfunction in the kidney, joints and reproductive systems (Ogwuegbu and Muhanga, 2005; Ferner, 2001). Lead also causes poor development of the grey matter in children leading to poor intelligence quotient (Udedi, 2003).

Values recorded in fish tissues for $\mathrm{Cd} 0.001 \pm 0.001,0.004 \pm 0.001 \mu \mathrm{g} / \mathrm{g}$ fat stations 1 and 3 respectively were within safe limit. However, the Cd concentration at station $2(0.02 \mu \mathrm{g} / \mathrm{g})$ was higher than the specified safe limit set by WHO (1985) and CIFA (1994). This implies that the Taylor Creek is polluted. (Cadmium poising pose problems such as lung disease, abnormal cramps and muscular weakness and ultimately death, if exposure to Cd is prolonged. Similar assertions were made by INEC AR (2000); European Union (2002), and Young (2005). 


\section{Conclusion:}

Heavy metals are known to affect aquatic organisms in the water and, the accumulation of heavy metal in an aquatic environment has direct consequences on man and the ecosystem. The levels of all metals detected in fish tissues except $\mathrm{Zn}$, were higher than the specified acceptable limits set by statutory bodies for food fish at all the stations of the study. This indicates that the Taylor Creek is polluted. Fish from the creek were contaminated to such levels that could pose potential hazards when consumed. This has serious implications in view of the growing population which depend on the Taylor Creek as source of fish supply to meet protein demand.

\section{References:}

[1] Agbozu, I.E., Ekweozor, I.K.E. and Opuene, K. (2000).Survey of Heavy Metals in Synodontis clams in the Niger Delta Area of Nigeria. Int. J. Environ. Sic Tech 4(1): 93-97.

[2] Agbozu, I.E and Ekweozor I.K.E (2001). Heavy Metals in a non-tidal Fresh water swamp in the Niger Delta Areas of Nigeria J. Sci., 2 175-182.

[3] Agbozu, I.E. and Ekweozor I.K.E. (2004). Heavy metals in Sediments from Lower Taylor Creek in the Niger Delta Area of Nigeria African J. Sic 5(1) 1043-1049.

[4] Aghoghovwia. O.A (2008). Assessment of Industrial and Domestic Effluent/Effects on Fish Species Diversity of Wary River, Delta State Nigeria. PhD thesis university of Ibadan, Ibadan Nigeria.

[5] Brock, T.D. (1985). A Euphoric Lake Mendota Wisconsin Springer, Verlog N.Y. Pp. 308

[6] CIFA (Committee for Inland Fisheries of Africa) (1994). Review of Pollution in the African Aquatic Environment, FAO Tech Paper No. 25, 118 Pp.

[7] Deb, S.C and Santra S.C. (1997). Bioaccumulation of heavy Metals in Fishes: An vivo experimental study of sewage Fed ecosystem The Environmentalist 17:27-32.

[8] European Union (2002). Heavy metals in wastes, European commission on environment http:ec.europa.eu/environment/waste/studies/pdf/heavy-metals report. Pdf).

[9] Gbaruko, B.C, and Friday, O.U (2007). Bioaccumulation of heavy metals in some Fauna and Flora. Int. J. Environ. Sci. Tech, 4(2): 197-202.

[10] Institute of Environmental conservation and Research/INECAR (2001). Position paper Against Mining in Rapu-Rapu, Published by INECAR, Ateneo de naga University Philipines www.adnu.edu.Ph./instututes/inecar/pospaper.asp).

[11] Glosh. Hayat, S., Javed,M. and Razzao, S., (2007) Growth Performance of Metal stress: Pakistan veterinary. Journal .V.27(1) P. $8-12$.

[12] Glosh, M. and Singh, S.P. (2005). Review on phytoremediation of heavy Metals and utilization of its by products: Applied Ecology Research V.3 (1) P. 1-18.

[13] Kumar, A. (2004). Water Pollution: New Delhi, A.P.H Publishing Corporation P.199.

[14] Lenntech Water treatment and Air Purification (2004). Water Treatment, Published by Lenntech, Rotterdam sewege Netherlands www.excelwater.com/thp/filters/water purification.htm.

[15] Obasohan E.E. Oronsaye J.A.O and Obano, E.E. (2006).Heavy metal concentrations in Malapterus electrics and Chrysicthysnigrodigitatus from Ogba River in Benin city Nigeria. African Journal of biotechnology Vol. 5 (10) $974-982$.

[16] Ogwuegbu, M.O.C and Muhanga, W. (2005) Investigation of Lead Concentration in the blood of people in the copper belt province of Zambia, J. Environ(1): 66-75.

[17] Okoye, B.C.O., Afolabi, O.A. and Ajao E.A. (1991). Heavy metals in the Lagos Lagoon sediments intern. J. Environmental Studies Vol. 37:35-41.

[18] Omoniyi, I.T., Akegbejo-Samson, Y and Adeosun, F.I (2006). Heavy metals in some commercial fish in Ikere-gorge, Oyo State, Nigeria. Asset series A. 2006 6(2): 311-316.

[19] Omoregie, E., Okonkwo, M.O., Ezashi A.C. and Zoakah, A.L (2002). Metal concentration in water column, benthic macroinvertebrate and Tilapia from Delimit River.

[20] Parson, T.R (1995). Pollution impacts on marine biology. In encyclopedia of environmental biology. Vol. 3: Pp. 157-170.

[21] Skjelvale B.L., Anderson, T., Jense, J.P. and moiseenko, T. (2001). Heavy surveys in the Nordic Lakes. Concentration, Geographic patterns and relation to critical limits. Ambio xxx(1): 2-10.

[22] Udedi, S.S. (2003). From Guinea Worm scourge to metal Toxicity in Ebonyi State; Chemistry in Nigeria as the New Millennium, unfolds, 2(2):13-14.

[23] World Health Organization (1985). Guidelines for drinking water profiles. Toxicity summary for Cadmium

[24] Young, R.A(2005). Toxicity Profiles: Toxicity summary for Cadmium Risk Assessment information system RAIS University of Tennessee (rais ornl. (gov./tox/ profiles/Cadmium.shtml.) 